\title{
The use of prescribed services marketing strategies by South African advertising agencies
}

\author{
K.R. Coman \\ Department of Business Administration, Rhodes University, P.O. Bex 94, Grahamstown, 6140 Republic of South Africa
}

Received 7 November 1988; accepted 10 January 1989

\begin{abstract}
Traditionally, marketing has been characterized by a lack of discrimination between tangible products and intangible services. Many marketing theorists presently subscribe to the view that the parameters of service exchanges are so different as to render conventional, product-based marketing paradigms invalid. However, definitive services marketing normatives remain limited in both range and scope. The author investigates specific services marketing strategies that have been prescribed in the services marketing literature. These strategies are assessed in terms of their actual usage amongst a sample of 44 advertising agencies. The research findings revealed that: (i) five marketing/managerial strategies were in common use - service quality, creativity, client-bonding, planning strategically, and operating efficiently; (ii) advertising agencies' freedom to adopt broader portfolios of services marketing strategies was constrained by their openness to client demands, and their emphasis upon having agency personnel serve as tangible service proxies. The implications of these findings and future research avenues in services marketing are discussed.
\end{abstract}

Bemarking is tradisioneel gekenmerk deur 'n gebrek aan onderskeid tussen tasbare produkte en ontasbare dienste. Talle bemarkingsteoretici steun tans die beskouing dat die parameters vir die ruil van dienste so uiteenlopend van aard is dat dit die konvensioneel aanvaarde paradigmas, wat op die bemarking van produkte berus, ongeldig maak. Toereikende dienstebemarkingsnorme bly egter nog beperk t.o.v. sowel die omvang daarvan as hul dekkingswydte. Die outeur ondersoek spesifieke dienstebemarkingstratigieë wat in die dienstebemarkingsliteratuur voorgeskryf word. Hierdie strategieë word geëvalueer t.o.v. die werklike toepassing daarvan deur 'n steekproef van 44 reklame-agentskappe. Die ondersoek toon dat: (i) vyf bemarkings-/bestuurstrategieë algemeen in gebruik is, nl. diensgehalte, skeppingskrag, kliëntlojaliteit, strategiese beplanning en doeltreffende bedryfsmetodes; en (ii) die vryheid van reklame-agentskappe om 'n breër reeks dienstebemarkingstrategieë toe te pas, beperk word deur hul ontvanklikheid vir die eise van kliënte asook hul klem dat personeel van agentskappe as tasbare plaasvervangers vir diens moet optree. Die implikasies van hierdie bevindinge en toekomstige navorsingsmoontlikhede op die gebied van dienstebemarking, word bespreek.

\section{Introduction}

The purposes of this article are: (1) to present an overview of the literature dealing with the unique characteristics and problems of marketing services; and (2) to reveal, and comment upon, the findings of a national survey amongst managers of service firms (advertising agencies) that sought to: (a) identify the marketing/managerial strategies they use, and (b) to establish the degree to which marketing strategies advocated in the literature are actually reported by managers of service firms.

\section{Services are different}

In the past, a manufactured 'product' was the primary analytical and conceptual construct in most spheres of marketing thought. Where acknowledged, serviceofferings were considered to be amenable to the same marketing strategies and approaches as applied to products (McCarthy, 1964: 38-40).

Yet from the late 1970s, a broadening consensus has emerged that services are sufficiently different from products to warrant the development and use of servicesspecific marketing strategies (e.g. Carman \& Langeard, 1980; Thomas, 1978).

At the heart of the contention that services marketing cannot be subsumed under a product marketing rubric lie four unique service characteristics (Berry, 1980):

Intangibility is widely regarded as the most fundamental and important differentiating criterion between a service and a product (e.g. Hawes \& Arndt, 1979; Shostack, 1977; Thomas, 1978). Whereas a product is primarily a physical object that can be tasted, touched, seen, readily perceived and manipulated; a service is intrinsically incorporeal - it is an act, a performance, or a promise. Thus, unlike products, services can neither be directly and physically sensed nor are they easy to define, formulate, or mentally conceptualize. The quality of intangibility is of great consequence to services marketing for two reasons.

1. All services marketing programmes have to grapple with the problems presented by the ubiquitous ambiguities (or 'intangibility blocks') that pervade the minds of service customers and employees alike (Rushton \& Carson, 1985).

2. Intangibility stands as the locus for the three remaining unique characteristics of a service.

Heterogeneity incorporates two notable considerations: performance variability and market positioning. Services have a high potential for performance variability. Even in the case of services whose operating systems are firmly controlled and minutely detailed, the level of service quality can differ from one transaction to the next. 'In a service business, you find that you're dealing with something that is primarily delivered by people to people. People's performance day in and day out fluctuates up and down. 
Therefore the level of consistency that you can count on and try to communicate to the customer is not a certain thing.' (Knisely, 1984: 25). Normann (1984: 8) aptly refers to the 'moment of truth' that arises when a service employee and customer interact. The respective behaviours and performance-outcomes that actually happen during a given moment of truth are (i) largely beyond the control of the service organization, and (ii) have a direct bearing upon the success of the service encounter as viewed by the two parties concerned (Schneider, 1980).

In terms of market positioning, heterogeneity raises the vital strategic question of where a particular service organization wishes to be positioned on a customization-standardization' continuum (Levitt, 1972, 1976; Surprenant \& Solomon, 1987). At the customization extreme, the service organization will deliberately encourage customer heterogeneity by structuring and staffing itself in such a way as to be able to appeal to those clients requiring service solutions that are unique to their individual problems and circumstances. Conversely, service standardization involves the detailed design of uniform (necessarily limited) offerings that are carefully targeted upon the particular needs and profiles of defined segments of service customers; (e.g.) a fastfood franchise or budget hotel chain.

Inseparability refers to two interrelated service attributes. Firstly, the sub-processes of selling, creating, delivering, and consuming a service often require the direct interaction of service employees and customers (e.g. Gronroos, 1984; Normann, 1984; Schneider, 1980; Surprenant, Czepiel \& Solomon, 1985). In such cases, the degree of service quality provided, or indeed whether a transaction takes place at all, is in large measure a function of highly personal and acutely situational-contingent buyer-seller interactive processes.

Secondly, services are often sold, created, delivered, and consumed almost literally simultaneously and in that sequence; (e.g.) a restaurant meal or an advertising campaign. Products, on the other hand, are first created, then sold, then delivered, and finally consumed with often lengthy time-delays between each stage; (e.g.) motor vehicles, power tools, office supplies, or hydraulic valves.

Inseparability poses certain marketing problems.

1. Inseparability forces each service organization to make a deliberate decision governing its policy towards customers. Two alternatives exist in this regard.

- Either the service firm must treat customers as fully integrated 'members' of its organization (Lovelock \& Young, 1984) even to the extent of casting them into the role of 'partial employees' (Mills, Chase \& Margulies, 1983). (Everyday examples of this approach are professional consultations in the medical, legal, or business services fields.) This customer handling strategy's success hinges upon, inter alia, customers' willingness and ability to acquire and act in accordance with an organizationally mediated suite of service creation and delivery skills (Bowen \& Jones, 1986).
- Or the service organization opts to 'decouple' itself from a direct, personal involvement with individual customers (Chase \& Tansik, 1983). The rationale here is that the random nature of customer demands serves to disrupt the smooth and efficient operation of the service organization; (e.g.) bank ledger-keeping schedules may fall behind because of recording staff having to respond to unpatterned sequences of nonuniform client queries.

A decoupling customer strategy involves shielding or buffering the innermost technical core of the organization from direct customer impositions. There are many ways to accomplish this, for instance; by instituting scheduling procedures, having 'front office' reception/liasion staff, or in extreme cases, mechanizing the service process and moving it off-site (e.g.) bank ATMs.

2. The need for close customer-employee interaction calls for a direct-distribution infrastructure in which either the service is conveyed to the customer via a geographically dispersed web of mini 'service factories' (e.g. bank branches) or attempts are made to draw the customer to a sizable, centrally located service facility (e.g. a national advertising agency or residential university) (Doyle \& Corstjens, 1983).

3. Service quality-outcomes are greatly dependent upon personal interactive processes; which in turn transmute 'personnel' matters (such as staff motivation, work values, attitudes, and organizational climate) into key marketing variables (Gronroos, 1984).

Perishability means that services cannot be saved or stored. For whereas a product can be manufactured and stockpiled in advance of demand, and unexpected demand-surges managed via inventoried buffer-stocks, a service organization has no recourse to such commonplace logistical practices. The service firm thus faces a continual problem of balancing relatively inflexible service supply capabilities with fluctuating market demand patterns (Sasser, 1976). In periods of unanticipated high demand, customers who cannot be served and are turned away represent an immediate lost profit opportunity. Similarly, hasty and incongruent attempts to expand the short-term rate of service transactions so as to match customer demand invite the risk of incurring an unpredictable and pervasive deterioration in service quality.

Reciprocally, the service organization represents a service infrastructure or capability 'in being'. This means that in times of slack demand, service production resources (personnel and fixed assets) can neither be turned to alternative purposes (e.g. producing for inventory) nor readily down-scaled so as to correspond with current demand - unfilled cinema, restaurant and airline seats, hospital beds, or hotel rooms equate to business that has been lost forever.

\section{Services marketing prescriptions}

Given the unique characteristics and problems associated with marketing services, many authorities contend that it is imperative to adopt specialized services 
Table 1 Recommended marketing strategies to counter unique service problems

\begin{tabular}{|c|c|}
\hline Unique service feature & Marketing strategies to counter problems \\
\hline Intangibility & $\begin{array}{l}\text { Generic strategy: 'Intangibility Reversal' } \\
\text { 1. Stress tangible cues/service proxies. } \\
\text { 2. Use personal information sources. } \\
\text { 3. Stimulate word-of-mouth communications. } \\
\text { 4. Create a strong organizational image. } \\
\text { 5. Develop an accurate, lucid price structure. } \\
\text { 6. Engage in post-purchase communication. }\end{array}$ \\
\hline Heterogeneity & $\begin{array}{l}\text { Generic strategy: 'Continuum Shift' } \\
\text { (Either) } \\
\text { 1. Standardize (industrialize) the service. } \\
\text { (or) } \\
\text { 2. Customize the service. }\end{array}$ \\
\hline Inseparability & $\begin{array}{l}\text { Generic strategy:'Dualistic Marketing' } \\
\text { 1. 'Internal marketing' - building customer service orientation within the organization. } \\
\text { 2. Emphasize selection, training of customer contact personnel. } \\
\text { 3. Manage customers - either as 'partial employees' or by 'decoupling' them from } \\
\text { creation/delivery operations. } \\
\text { 4. Use multisite location distribution strategy. }\end{array}$ \\
\hline Perishability & $\begin{array}{l}\text { Generic strategy:'Demand Management with Organizational Flexibility' } \\
\text { 1. Use strategies to cope with fluctuating demand. } \\
\text { 2. Make simultaneous adjustments in demand ('demarketing') and capacity to achieve a closer } \\
\text { match between demand and supply. }\end{array}$ \\
\hline
\end{tabular}

Adapted from Zeithaml, et al., (1985: 35)

marketing strategies (e.g. Berry, 1980; Gronroos, 1984; Shostack, 1977; Thomas, 1978).

Zeithaml, Parasuraman \& Berry (1985) developed a comprehensive literature review of the various services marketing strategies that have been recommended to counter services problems. Table 1 summarizes the work of Zeithaml, et al., (1985), and what follows is a brief description of the four generic services marketing strategies so evinced:

\section{Intangibility reversal}

Intangibility should be addressed by taking steps to make the service as tangible and as concrete as possible.

\section{Continuum shift}

Heterogeneity imposes a need for the service organization to decide either to standardize ('industrialize' Levitt, 1972, 1976) its services or to offer them on a customized basis.

\section{Dualistic marketing}

Inseparability should be resolved by an integrated, yet bi-polar marketing effort. One marketing thrust should be geared to objectives within the normal external consumer and competitive arenas, but the second should focus upon internal organizational arrangements suited to the optimalization of service quality and productivity.

\section{Demand management with organizational flexibility}

Perishability requires that the service firm continuously balance market demand and supply capacity to best effect. Recommended strategies involve making purposeful interventions into the market to regulate demand, whilst simultaneously designing the service creation and delivery system so as to be readily capable of smoothly progressive expansion and contraction.

\section{The present study}

The present study had a two-fold justification.

1. The services literature is consistent regarding the crucial importance of service industries to any modern economy. The following quotation from Riddle (1986: 1) reflects the views of many authorities publishing in this field: 'Services lie at the very hub of economic activity in any society.....

Yet the service sector is one of the least understood portions of our global economy. The service sector receives only minimal attention in country analyses, policy deliberations, or development funding strategies.'

The present study was thus intended as a modest contribution to the challenge of developing a more comprehensive insight into the modern service sector.

2. The marketing operations of service organizations provoke an array of perplexing research questions; many of which remain imperfectly answered even in countries with a well-established services marketing research tradition (Zeithaml, et al., 1985).

Service industries as a whole are notable for their wide range and diversity. It was therefore judged impractical 
to favour the ideal research mission of obtaining a representative coverage of all service industries. Consequently, the more workable goal of studying the marketing practices of a single service industry was selected. To this end, the South African advertising agency industry was settled upon.

1. By definition, an advertising agency's modus operandi should reflect a forceful and pervasive marketingdriven business philosophy - and marketing was the central research interest present.

2. Advertising agencies operate within a highly turbulent and competitive environment (e.g. Benn, 1978; Newton, 1965).

3. On the basis of (1) and (2) above, it was inferred that, perhaps more so than most other service industries, the fortunes of advertising agencies would be closely correlated with their capacity to adroitly execute wellcrafted marketing strategies.

The study's target respondent was the managing director (chief executive officer) of each sample firm. This decision was greatly influenced by two factors.

1. The managing director would be the one person best placed and qualified to articulate factual and holistic insights into the agency's business philosophy and marketing strategies.

2. Independent observation of the managerial behaviours exhibited by advertising agency managing directors suggested that they were typically fully immersed in their agency's daily operations. Hence, their understanding of the fine texture and reality of client-service performances would not be unduly masked or distorted by hierarchical detachment.

\section{Research objectives}

The following research objectives emerged from the literature review.

1. To determine what the managing directors of serviceintensive organizations actually regard as being the most valid and practical marketing/managerial strategies.

2. To establish the degree to which sample firms make use of prescribed marketing strategies to overcome problems caused by intangibility, heterogeneity, inseparability, and perishability.

\section{Methodology}

The sample comprised all 141 registered advertising agencies listed in the Marketing Mix, Promodata directory. A questionnaire, covering letter, and replypaid envelope were mailed to the managing director of each advertising agency. Reminder postcards were sent to all respondents three weeks later. Forty-four usable questionnaires $(31,2 \%)$ were received by the cut-off date.

In order to ensure that the study would provide as reliable and valid information as possible, the questionnaire was pilot-tested via personal interviews. Observations made at the time indicated that no material changes to the draft questionnaire were necessary.

\section{The questionnaire}

The questionnaire contained two sections. The first section addressed Objective 1 . It invited respondents to set down in their own words the crucial marketing/ managerial strategies that they upheld for their

Table 2 Marketing/managerial strategies considered to be crucial to organizational success

\begin{tabular}{|c|c|c|c|c|c|c|c|c|}
\hline \multirow[b]{3}{*}{ Claimed success strategies } & \multicolumn{8}{|c|}{ Respondent rankings } \\
\hline & \multicolumn{2}{|c|}{$\begin{array}{l}\text { The most } \\
\text { important }\end{array}$} & \multicolumn{2}{|c|}{$\begin{array}{l}\text { Second most } \\
\text { important }\end{array}$} & \multicolumn{2}{|c|}{$\begin{array}{l}\text { Third most } \\
\text { important }\end{array}$} & \multicolumn{2}{|c|}{$\begin{array}{c}\text { Fourth most } \\
\text { important }\end{array}$} \\
\hline & No & $\%$ & No & $\%$ & No & $\%$ & No & $\%$ \\
\hline Creativity/ability to innovate & 13 & 29,5 & 7 & 15,9 & 2 & 4,5 & 2 & 4,5 \\
\hline Service excellence/quality/expertise & 12 & 27,3 & 13 & 29,5 & 8 & 18,2 & 1 & 2,3 \\
\hline Regular client contact/accessible to clients & 10 & 22,7 & 3 & 6,8 & 2 & 4,5 & 1 & 2,3 \\
\hline Develop a long-term client relationship/match employees to clients & 7 & 15,9 & 6 & 13,6 & 5 & 11,4 & 2 & 4,5 \\
\hline Know client needs/products/background & 5 & 11,4 & 3 & 6,8 & 5 & 11,4 & 4 & 9,1 \\
\hline \multicolumn{9}{|l|}{ Agency corporate plan/growth strategies/market strategies/ } \\
\hline management systems & 6 & 13,6 & 6 & 13,6 & 2 & 4,5 & 3 & 6,8 \\
\hline Efficient administration/cost efficient management & 2 & 4,5 & 3 & 6,8 & 6 & 13,6 & 6 & 13,6 \\
\hline Dedicated/motivated employees & 1 & 2,3 & 3 & 6,8 & - & - & 1 & 2,3 \\
\hline Corporate image & 2 & 4,5 & 1 & 2,3 & 2 & 4,5 & 1 & 2,3 \\
\hline Competitive strategy & 1 & 2,3 & 2 & 4,5 & 2 & 4,5 & 4 & 9,1 \\
\hline Service technology & 1 & 2,3 & - & - & 3 & 6,8 & 1 & 2,3 \\
\hline Non-personal promotion & - & - & 4 & 9,1 & - & - & 5 & 11,4 \\
\hline Personal promotion & - & - & - & - & 4 & 9,1 & 3 & 6,8 \\
\hline Other & 1 & 2,3 & 1 & 2,3 & - & - & 2 & 4,5 \\
\hline$n=44$ & & & & & & & & \\
\hline
\end{tabular}

- Unprompted responses 
respective organizations. Respondents were also asked to rank these strategies in order of their perceived importance.

The second section comprised a series of rating questions designed to ascertain respondents' employment of services marketing strategies (Objective 2). Each question laid out a particular strategy relating to one of the four unique service characteristics (intangibility, heterogeneity, inseparability, and perishability). Respondents were requested to indicate the extent to which each strategy was applicable to their organizations. A four-point Likert-type interval scale (1: Not Applicable; 4: Highly Applicable) was used.

\section{Research findings}

Marketing/managerial strategies considered to be of crucial importance by respondents

As Table 2 demonstrates, surveyed advertising agencies believed that performance in their industry rested, primarily, upon an individual firm's ability to implement five complementary marketing/managerial strategies:

Providing clients with a service of excellent quality

(Cited by a total of $56,8 \%$ of respondents as the most/ second most important strategy.) Overall, $75 \%$ of respondents included this strategy within the first three rankings of importance.

The provision of creative and innovative advertising

(Cited by a total of $45,4 \%$ of respondents as the most/ second most important strategy.)

\section{Client-bonding}

Drawing very close to clients by: Keeping in regular contact, being open and accessible to clients' requests, endeavouring to build up a long-term relationship, matching the characteristics and abilities of service staff to client-profiles, and striving to truely understand clients' needs, make-ups and problems. (The vital nature of these types of service attributes and client-strategies was underscored by the fact that all respondents deemed them to lie within the first four rankings of importance.)

\section{Strategic planning and management}

Developing and working in terms of a definite strategic plan that incorporates directional guidance for organizational growth and market segmentation was highly regarded by the $38,5 \%$ of respondents who included this attribute within the first four rankings of importance, whilst $27,2 \%$ considered it to be the most second-most important attribute.

\section{Internal efficiency}

Managing operations, work- and cash-flows to best effect. (Cited by a total of $27,2 \%$ of respondents as the third/fourth-most important strategy.)

The information contained in Table 2 fully supports the contention that a valid and practical services marketing strategy for a professional service business is to build a close 'partnership' relationship with individual clients (Bloom, 1984). Also with reference to Table 2, it is noteworthy that the main identified marketing strategies evince a degree of correspondence with received parallel thinking on the subject of competitive strategy, According to Porter (1980), an organization should cast its competitive approach in terms of three generic competitive strategies: differentiation, focus, and low cost. On the basis of these findings, it can be tentatively proposed that sample firms strove for competitive advantage primarily through a differentiation-linked strategy that is executed by trying (relative to other agencies) to: offer a consistently high level of service quality; be more creative and innovative; and be more tightly bonded to their client portfolios.

An interesting finding was the importance assigned to having a formal and systematic strategic planning activity. As noted earlier, approximately a third of

Table 3 Applicability of recommended intangibility reduction strategies

\begin{tabular}{|c|c|c|c|c|c|c|c|c|c|}
\hline \multirow[b]{3}{*}{ Intangibility strategies } & \multirow{3}{*}{$\frac{\text { Mean rating }}{(\text { Scale:4-1) }}$} & \multicolumn{8}{|c|}{ Applicability } \\
\hline & & \multicolumn{2}{|c|}{ Highly } & \multicolumn{2}{|c|}{ Usually } & \multicolumn{2}{|c|}{ Moderately } & \multicolumn{2}{|c|}{ Not } \\
\hline & & No & $\%$ & No & $\%$ & No & $\%$ & No & $\%$ \\
\hline Stress personal contact with clients & 3,9 & 39 & 88,6 & 5 & 11,4 & - & - & - & - \\
\hline Encourage repeat client contact & 3,8 & 36 & 81,8 & 6 & 13,6 & 1 & 2,3 & 1 & 2,3 \\
\hline Stress staff expertise/efficiency to clients & 3,6 & 31 & 70,4 & 8 & 18,2 & 4 & 9,1 & 1 & 2,3 \\
\hline Corporate logo, signage, stationery & 3,6 & 34 & 77,3 & 6 & 13,6 & 1 & 2,3 & 3 & 6,8 \\
\hline Use standardized fee structure & 3,0 & 18 & 40,9 & 13 & 29,5 & 8 & 18,2 & 5 & 11,4 \\
\hline Office decor/design & 2,8 & 14 & 31,9 & 11 & 25,0 & 13 & 29,5 & 6 & 13,6 \\
\hline Stress service technology in client encounters & 2,3 & 7 & 15,9 & 9 & 20,5 & 18 & 40,9 & 10 & 22,7 \\
\hline Formally promote word-of-mouth & 1,7 & 3 & 6,8 & 7 & 15,9 & 9 & 20,5 & 25 & 56,8 \\
\hline $\begin{array}{l}\text { Informally promote word-of-mouth } \\
n=44\end{array}$ & 1,7 & 2 & 4,5 & 4 & 9,1 & 18 & 40,9 & 20 & 45,5 \\
\hline
\end{tabular}

- 4 = highly applicable; 3 = usually applicable; $2=$ moderately applicable; $1=$ not applicable 
respondents indicated that they viewed strategic planning as a significant and desirable contribution to the successful management of an advertising agency. By exclusion, this also suggests that for the majority, strategic planning is either not practised or that it is conducted on an intuitive, ad hoc basis.

In summary, the main conclusions to be drawn about sample agencies' marketing and managerial strategies are that:

(a) their overriding concern was to create and thereafter reinforce a tight bond or fusion between themselves and their individual clients;

(b) agencies would seek to operate under a prudent and cost-effective managerial regimen;

(c) certain (but by no means all) agencies laid emphasis upon having formalized strategic planning; and

(d) competitive strategy may center upon differentiation via: service quality, innovation, creativity, and close client loyalty.

\section{Adoption of recommended services marketing strategies \\ Strategies relating to intangibility}

Table 3 reports the information collected upon the perceived applicability of various strategies related to intangibility. Given that one of the prime aims of services marketing is to reduce client-perceived uncertainty and ambiguity about the service, prescribed intangibility amelioratives involve the provision of tangible and concrete service proxies. Of the nine intangibility strategies tested, the most widely adopted were: personal contact with clients; repeat clientcontact; emphasizing staff expertise and efficiency; and corporate image reinforcement via (e.g.) corporate logos, signage, and letterheads. Approximately nine in every ten respondents made at least moderate use of a standardized fee structure with $40,9 \%$ indicating that this strategy was highly applicable to their organizations.
Deliberately creating and manipulating facilities design and office decor (Berry, 1980) so as to convey an appropriate 'atmosphere' or service-environment was used, at least to some extent, by $86,4 \%$ of sample firms. Slightly over a third of sample firms $(36,4 \%)$ reported high-to-usual use of service technology as a means of making their services more tangible to their clients. Strategies to foster a distinctive corporate image through the medium of formal and informal word-of-mouth campaigns found little favour amongst respondents.

\section{Strategies relating to service heterogeneity}

Table 4 depicts the data collected for the six heterogeneity-related strategies investigated. When viewed holistically, Table 4 indicates that the majority of sample firms took client-heterogeneity for granted. Specifically: (a) a total of $86,3 \%$ of respondents stated that being able to customize their services to reflect unique client needs (a source of heterogeneity) was highly/usually applicable to their firms; and (b) in terms of strategic posture and market positioning, two distinct profiles emerged from the response patterns relating to the strategies: cater for the needs of a diverse array of client-markets; offer a limited range of specialized, standardized services; and focus upon a defined client profile within a specific market. Approximately four in every ten sample firms sought to focus upon specific clients within specific markets, whilst the balance pursued a more undifferentiated market strategy:

\begin{tabular}{lcc} 
& \multicolumn{3}{c}{ Highly/usually applicable } \\
& No & $\%$ \\
\hline $\begin{array}{l}\text { Focused client/market profile } \\
\text { (Heterogeneity reduction) }\end{array}$ & 19 & 43,2 \\
$\begin{array}{l}\text { Diverse client/markets } \\
\text { (Heterogeneity provocation) }\end{array}$ & 27 & 61,4 \\
\hline
\end{tabular}

Table 4 Applicability of recommended heterogeneity reduction strategies

\begin{tabular}{|c|c|c|c|c|c|c|c|c|c|}
\hline \multirow[b]{3}{*}{ Heterogeneity strategies } & \multirow{3}{*}{$\frac{\text { Mean rating }}{(\text { Scale: } 4-1)^{a}}$} & \multicolumn{8}{|c|}{ Applicability } \\
\hline & & \multicolumn{2}{|c|}{ Highly } & \multicolumn{2}{|c|}{ Usually } & \multicolumn{2}{|c|}{ Moderately } & \multicolumn{2}{|c|}{ Not } \\
\hline & & No & $\%$ & No & $\%$ & No & $\%$ & No & $\%$ \\
\hline \multicolumn{10}{|l|}{ Customization: adapt/tailor services to unique client } \\
\hline needs & 3,6 & 32 & 72,7 & 6 & 13,6 & 5 & 11,4 & 1 & 2,3 \\
\hline Operate with predetermined service quality standards & 3,2 & 16 & 36,3 & 21 & 47,8 & 6 & 13,6 & 1 & 2,3 \\
\hline \multicolumn{10}{|l|}{ Use service-technology to assist in service } \\
\hline performance & 3,1 & 16 & 36,3 & 19 & 43,3 & 7 & 15,9 & 2 & 4,5 \\
\hline \multicolumn{10}{|l|}{ Cater for the needs of a diverse array of client } \\
\hline markets & 2,8 & 14 & 31,9 & 13 & 29,5 & 10 & 22,7 & 7 & 15,9 \\
\hline Offer a limited range of specialized, standard services & 2,7 & 16 & 36,4 & 6 & 13,6 & 16 & 36,4 & 6 & 13,6 \\
\hline \multicolumn{10}{|l|}{ Focus upon a defined client profile within a specific } \\
\hline market & 2,4 & 9 & 20,5 & 10 & 22,7 & 13 & 29,5 & 12 & 27,3 \\
\hline$n=44$ & & & & & & & & & \\
\hline
\end{tabular}

4 = highly applicable; 3 = usually applicable; $2=$ moderately applicable; $1=$ not applicable 
Moreover, respondents were equally divided between favouring and being averse to offering a limited range of specialized, standardized services:

Limited range of specialized, standardized services

\begin{tabular}{|c|c|c|}
\hline & No & $\%$ \\
\hline Highly/usually applicable & 22 & 50,0 \\
\hline Moderately/not applicable & 22 & 50,0 \\
\hline
\end{tabular}

(c) Viewed in combination, (a) and (b) above suggest the following conclusions relating to service heterogeneity.

(i) Some advertising agencies elected to follow a focused service/client business strategy, and to thereby reduce the effects of heterogeneity. Others were willing to operate more opportunistically in terms of wider, less targeted service/client parameters, but at the risk of provoking heterogeneity problems.

(ii) Irrespective, however, of the business strategy adopted, the clear majority of respondents strove to adapt and finely fettle specific services to clients' unique circumstances and needs.

In overall terms, a significant proportion of firms sought not to reduce heterogeneity by purposefully focusing upon the more predictable requirements of a specialized client-market niche. And, even amongst those having niche strategies, there was found to be a tendency to inspire heterogeneity problems by an admitted willingness to modify (within undefined limits) otherwise standardized services to suit client requirements.

\section{Strategies relating to service inseparability}

From the responses shown in Table 5, it is perceptible that the service characteristic of inseparability was considered to be endemic to the operations of sample firms. The greater number of respondents acknowledged this by indicating how imperative it was for them to: engage in open discussions with clients about their needs, employ client-liaison staff, and select clientcontact staff on the basis of having suitable personal attributes (or 'chemistry') vis-á-vis clients.

Of interest is the relatively low levels of applicability assigned to specific strategies that have been advanced as ways of reducing inseparability problems. The widely discussed strategy of buffering or protecting the service organization's 'technical core' from random external disruptions caused by unexpected client demands was found to be vigourously practised by only $9,1 \%$ of respondents; although a further $31,8 \%$ indicated that they usually tried to adhere to this strategy.

As originally envisaged, the existence of deeply rooted inseparability would create a need to methodically train, coach and develop staff within defined categories of work. Yet, surprisingly, the analysis revealed that having uniform procedures for training new staff was only weakly applicable to respondent firms.

\section{Strategies relating to service perishability}

A total of 16 rating questions were posed in order to determine the degree to which sample firms made use of prescribed strategies to match market demand to service supply capabilities. This study explored two states of demand: high demand, wherein existing service supply capabilities are outstripped; and low demand, where existing supply capabilities are under-utilized.

Table 6 reports claimed usage of recommended strategies to cope with high demand conditions. Arguably one of the most striking findings is the very low mean score $(1,4)$ against the strategy of turn away

Table 5 Applicability of recommended inseparability reduction strategies

\begin{tabular}{|c|c|c|c|c|c|c|c|c|c|}
\hline \multirow[b]{3}{*}{ Inseparability strategies } & \multirow{3}{*}{$\frac{\text { Mean rating }}{(\text { Scale: } 4-1)^{a}}$} & \multicolumn{8}{|c|}{ Applicability } \\
\hline & & \multicolumn{2}{|c|}{ Highly } & \multicolumn{2}{|c|}{ Usually } & \multicolumn{2}{|c|}{ Moderately } & \multicolumn{2}{|c|}{ Not } \\
\hline & & No & $\%$ & No & $\%$ & No & $\%$ & No & $\%$ \\
\hline \multicolumn{10}{|l|}{$\begin{array}{l}\text { Service provision is dependent upon open, honest } \\
\text { specific discussion of each client's needs and }\end{array}$} \\
\hline $\begin{array}{l}\text { circumstances } \\
\text { Employ staff whose primary responsibility is client }\end{array}$ & 3,8 & 36 & 81,8 & 7 & 15,9 & 1 & 2,3 & - & - \\
\hline liaison & 3,7 & 36 & 81,8 & 5 & 11,4 & 1 & 2,3 & 2 & 4,5 \\
\hline $\begin{array}{l}\text { Recruitment and selection of service staff reflects a } \\
\text { desire to hire people meeting client-mediated criteria } \\
\text { Separation exists between client liaison and service }\end{array}$ & 3,3 & 24 & 54,6 & 14 & 31,8 & 3 & 6,8 & 3 & 6,8 \\
\hline $\begin{array}{l}\text { processing/performance activities } \\
\text { Each employee works in terms of a set statement of }\end{array}$ & 2,2 & 4 & 9,1 & 14 & 31,8 & 12 & 27,3 & 14 & 31,8 \\
\hline performance objectives & 2,2 & 6 & 13,6 & 13 & 29,5 & 8 & 18,2 & 17 & 38,7 \\
\hline $\begin{array}{l}\text { Have uniform procedures for training new staff } \\
n=44\end{array}$ & 2,0 & 5 & 11,4 & 8 & 18,2 & 13 & 29,5 & 18 & 40,9 \\
\hline
\end{tabular}

- 4 = highly applicable; 3 = usually applicable; 2 = moderately applicable; $1=$ not applicable 
Table 6 Usage of recommended strategies to cope with periods of high demand

\begin{tabular}{|c|c|c|c|c|c|c|c|c|c|}
\hline \multirow[b]{3}{*}{ High demand strategies } & \multirow{3}{*}{$\frac{\text { Mean rating }}{\text { (Scale:4-1) }}$} & \multicolumn{8}{|c|}{ Usage } \\
\hline & & \multicolumn{2}{|c|}{ Always } & \multicolumn{2}{|c|}{ Usually } & \multicolumn{2}{|c|}{ Occasionally } & \multicolumn{2}{|c|}{ Seldom/never } \\
\hline & & No & $\%$ & No & $\%$ & No & $\%$ & No & $\%$ \\
\hline Employees work overtime & 3,5 & 29 & 65,9 & 10 & 22,7 & 1 & 2,3 & 4 & 9,1 \\
\hline Reassign employees to urgent projects & 3,1 & 17 & 38,6 & 20 & 45,5 & 3 & 6,8 & 4 & 9,1 \\
\hline Give priority to regular clients & 3,0 & 17 & 38,6 & 16 & 36,4 & 4 & 9,1 & 7 & 15,9 \\
\hline Hire extra part-time employees & 2,8 & 13 & 29,5 & 16 & 36,4 & 7 & 15,9 & 8 & 18,2 \\
\hline Subcontract work & 2,3 & 8 & 18,2 & 11 & 25,0 & 13 & 29,5 & 12 & 27,3 \\
\hline Hire extra full-time employees & 2,0 & 9 & 20,5 & 5 & 11,4 & 7 & 15,9 & 23 & 52,2 \\
\hline Let work fall behind & 1,6 & 1 & 2,3 & 4 & 9,1 & 14 & 31,8 & 25 & 56,8 \\
\hline $\begin{array}{l}\text { Turn away business } \\
n=44\end{array}$ & 1,4 & 1 & 2,3 & 1 & 2,3 & 11 & 25,0 & 31 & 70,4 \\
\hline
\end{tabular}

4 = always use; 3 = usually use; 2 = occasionally use; 1 = seldom or never use

Table 7 Usage of recommended strategies to cope with periods of low demand

\begin{tabular}{|c|c|c|c|c|c|c|c|c|c|}
\hline \multirow[b]{3}{*}{ High demand strategies } & \multirow{3}{*}{$\frac{\text { Mean rating }}{(\text { Scale:4-1) }}$} & \multicolumn{8}{|c|}{ Usage } \\
\hline & & \multicolumn{2}{|c|}{ Always } & \multicolumn{2}{|c|}{ Usually } & \multicolumn{2}{|c|}{ Occasionally } & \multicolumn{2}{|c|}{ Seldom/never } \\
\hline & & No & $\%$ & No & $\%$ & No & $\%$ & No & $\%$ \\
\hline Call on existing, past or potential clients & 3,5 & 29 & 65,9 & 11 & 25,0 & 1 & 2,3 & 3 & 6,8 \\
\hline Share out available work amongst existing employees & 2,8 & 15 & 34,1 & 15 & 34,1 & 6 & 13,6 & 8 & 18,2 \\
\hline Lay off part-time employees & 2,6 & 19 & 43,1 & 4 & 9,1 & 5 & 11,4 & 16 & 36,4 \\
\hline Expand service range to make fullest use of resources & 2,3 & 10 & 22,7 & 7 & 15,9 & 11 & 25,0 & 16 & 36,4 \\
\hline Increase promotion & 2,2 & 7 & 15,9 & 10 & 22,7 & 11 & 25,0 & 16 & 36,4 \\
\hline Seek subcontracting work & 1,7 & 8 & 18,2 & 1 & 2,3 & 6 & 13,6 & 29 & 65,9 \\
\hline Lay off full-time employees & 1,4 & 2 & 4,5 & 1 & 2,3 & 9 & 20,5 & 32 & 72,7 \\
\hline Offer price reductions & 1,1 & - & - & - & - & 6 & 13,6 & 38 & 86,4 \\
\hline$n=44$ & & & & & & & & & \\
\hline
\end{tabular}

" 4 = always use; 3 = usually use; 2 = occasionally use; 1 = seldom or never use

business. Only two respondents indicated that they always or usually made use of this strategy: for the rest, their policy was to accept additional business regardless. This finding strongly suggests that sample firms did not, on the whole, avail themselves of 'demarketing' opportunities (Kotler \& Levy, 1971) and so proactively manage, control, or reduce disruptive demand-surges.

Having taken on a workload that would push their firms to or beyond full capacity, how do respondents cope?

Table 6 shows that having committed to extra work, respondents wished to deliver on their promises by not letting work fall behind; a strategy whose mean rating score was only 1,6 and which was wholly or for the most part spurned by no less than $88,6 \%$ of respondents. Sample firms also tended to eschew the elective of hiring extra full-time employees (mean rating score 2,0 and $68,1 \%$ whole or partial rejection).

In default of the above strategies, ways and means were sought to temporarily expand the organization's service production and delivery capacity. As can be seen in Table 6, demanding that employees work overtime was a popular option. To a somewhat lesser, but still notable, extent the practices of: reassigning employees to urgent projects, giving priority to regular clients, and taking on part-time employees were evident.

Overall, in periods of high demand respondents were reluctant either to limit their acceptance of new work or to discriminate objectively between clients. Instead, they appeared to have a policy of contracting for all available business and then adopting whatever short-term expediencies were necessary to carry them through to completion. On this basis it can be postulated that sample firms were so sensitive to the iron law of service perishability that they almost dared not pass up any chances to undertake new work assignments.

Table 7 considers strategies for dealing with a period of low demand. Sample firms tended to respond in three ways to reduced demand conditions. Firstly, they endeavoured to stimulate demand by increasing the intensity of their calls on existing, past or potential clients (mean rating score 3,5 with $90,9 \%$ of respondents 
indicating a strong reliance upon this strategy). Secondly, they placed a premium upon keeping their core service capabilities intact. This is evident from their reluctance to lay off full-time employees (mean rating score 1,4 and $93,2 \%$ claiming that they made only occasional or no use of this ploy), together with their ready willingness to share out available work amongst existing employees (mean rating score 2,8). Thirdly, given the above intentions, it can be expected that a typical sample firm's complement of part-time employees will be amongst the first to experience the negative consequences of a demand shortfall; and this is, indeed, what tends to happen - at least at certain agencies. Of the respondents $52,2 \%$ indicated that a policy of laying off part-time employees was always/ usually practised in times of weak demand.

Recommended strategies calculated to stimulate demand (other than that of calling on clients noted earlier) drew mixed responses. Increasing promotion (e.g. self-advertising) and expanding the range of services offered were intensively pursued by approximately four in ten sample firms, but were little used by the majority. Moreover, as can be seen in Table 7, a relatively small number of firms always/usually sought subcontracting work $(20,5 \%)$, whilst a bare $13,6 \%$ even toy with the strategy of offering price reductions.

When viewed in combination, Tables 6 and 7 create the picture of an industry that is largely driven by opportunity and managed by exingency. In times of high demand, there is a tendency to take on as much work as is available and thereafter to juggle organizational resources to complete it. Little by way of any proactive effort appears to be directed towards channelling or managing excess demand. Conversely, when demand shrinks respondent firms' repertoire of strategies primarily comprises efforts to stimulate work amongst a medley of current, past, and potential clients whilst preserving their respective pools of full-time employee expertise by shedding part-time staff.

\section{Conclusion}

The empirical evidence discussed in detail in the previous sections suggests that, consciously or otherwise, respondent firms are managed in ways that are generally in but limited accordance with recommended services marketing strategies.

1. A received view amongst respondents is that to be successful in the advertising industry it is vitally necessary to 'bond' the agency to each client. In services marketing terms, this will mean that a high priority is placed upon countering the negative effects of intangibility by making agency personnel serve as 'tangible' service proxies.

2. However, so great is the measure of importance attached to achieving effective personal encounters with clients, and so high is this objective elevated as a critical success factor, that grounds exist to suggest that this intangibility-reduction strategy may be pursued at the cost of an agency's wider freedom to resolve problems posed by heterogeneity and inseparability. Specific rationale for this conclusion are:

- the unpredictable pressures, inopportune demands, and organizational stress stemming from rampant client heterogeneity were regarded as natural and unavoidable aspects of the advertising industry. This perception is, arguably, most evident amongst agencies pursuing relatively undifferentiated servicemarket business strategies;

- the goal of securing an enduring agency-client bond was perceived almost to preclude the adoption of recommended inseparability strategies.

3. Intangibility was also found to be addressed by designing suitable environments within which agencyclient encounters could occur (eg. office decor). However, relatively little use was made of service technology and word-of-mouth opinion cultivation to create concrete impressions in the minds of clients.

4. In periods of excess demand, surveyed agencies tend to disregard (or were unaware of) latent possibilities to manage such demand proactively. At such times their preoccupation centered upon supply-side issues; such as pressing employees to work overtime and taking on part-time staff.

5. In periods of slack demand, a three-fold agency response was evident:

(a) revenue-generation via heightened client-contact;

(b) core-skills retention; and

(c) releasing part-time employees.

The overriding conclusion reached by this research is that marketing strategies adopted by advertising agencies are profoundly influenced by their perceived need to conform with a transcending business philosophy which requires the agency to be:

1. readily responsive to client demands, and

2. unreservedly dependent upon inconstant and subjectively gauged agency-client personal interactive processes.

The net effect of this is to limit advertising agencies' ability to adopt recommended services marketing strategies.

It follows, therefore, that services marketing strategies can be more comprehensively implemented only in the case of those advertising agencies which can successfully resolve a three-fold problem:

(a) developing an effective bond or fusion with clients;

(b) decoupling their internal operations from the vagarities and disruptions occasioned by client demands; (c) specializing and concentrating their efforts upon the needs of definite market niches.

\section{Implications of the research}

These research findings have important implications for the management of advertising agencies as well as for future services marketing research.

\section{Implications for advertising agency management}

1. The overall business-level strategies employed by advertising agencies are more alike than different. In 
essence, most agencies compete on the basis of only two closely corresponding strategies: (a) being creative and innovative, and (b) striving to bond themselves to their clients. This, in turn, means that:

- competitive barriers to entry are low (any creative and energetic individual(s) can establish an agency);

- sustainable competitive advantage, optimal market positioning, and perceived agency distinctiveness are elusive goals;

- services marketing strategies prescribed in the literature can often be only superficially practised.

However, these and other problems can be minimized by adopting business-level strategies that are materially different from those presently in widespread use. For example, the reconfiguration of an agency's strategy so as to elevate service technology to the forefront of its offerings could serve to ameliorate the limitations imposed by current stategies, whilst widening avenues of business opportunity and securing a more enduring competitive advantage.

2. Present services marketing doctrine lays emphasis upon overcoming the problem of intangibility by making a service as tangible as possible. To this end, advertising agencies could make more intensive use of the following: - technology (as noted above) in the service creation and delivery processes;

- informal word-of-mouth promotion;

- formal word-of-mouth promotion.

3. Definite opportunities exist for many individual agencies to practise a finer degree of client-segmentation and thereby to cater more closely for the needs of specific market niches. In this way, a discriminating agency would not only begin to systematically address the problem of service heterogeneity, but it might also benefit from a lack of direct competitive pressure through the protection afforded by its domination of a carefully selected, expertly treated, portfolio of accounts.

4. An interesting finding under inseparability (Table 5) was the relative neglect afforded uniform procedures for training new staff. This suggests that either new employees are expected to acquire relevant job-skills informally through subsequent hands-on experience or that suitably proficient staff are 'head hunted' and enticed away from competitors and client organizations. If true, the negative consequences that both practices must have upon service quality, organizational loyalty, and the goal of cementing stable client relationships are surely worthy of reflection by advertising agency executives.

5. Based upon the evidence in the research, attention should be paid to demand management, especially in periods when market demand is running close to an individual agency's maximum capacity. The seemingly common phenomenon of impetuously accepting incremental business may yield short-term rewards but at disproportionate long-term cost. A wiser policy may be to switch to a strategy of 'demarketing' at such times. 6. Unexplored possibilities may exist to counter demand contractions by; (eg.) examining ways and means to offer clients promotion financing packages, systematically canvassing for subcontracting work, and expanding the range of promotion services provided.

\section{Implications for future services marketing research}

1. As was strongly evident in this research, surveyed advertising agencies' adoption of an ultra-responsive, people-intensive business strategy served to limit the wider use of specific services marketing strategies. From the point of view of services marketing theory and research, the pervasive influence of corporate- or business-level strategy must be expressly acknowledged. Services marketing phenomena cannot thus be studied in isolation from overhanging strategic factors.

2. Notwithstanding the above observation, the services marketing strategies considered in this study were those which are assumed to address marketing problems arising from the various unique characteristics of services. But it has not yet been ascertained what the specific marketing problems are that service-intensive organizations face. Attention to specific marketing problems, not hypothetically useful strategies, would enable researchers to develop more practical and valid normatives than those presently in popular currency.

3 . The current research found that wide differences exist between sample firms in the strategic planning arena (Table 2). This serves to underscore just how very little is presently known about the contents and processes of service firms' corporate- and business-level strategic management. In this context, the nature, problems, and approaches appertaining specifically to competitive strategy are, to all intents and purposes, wholly unexplored.

4. The seemingly entrenched 'people-intensity' of certain service organizations (such as those studied here) suggests that a synthesis of research interests is desirable between the disciplines of marketing and organizational behaviour. Given the current South African reality, this point of interconnection must be seen to offer a vitally important business research avenue. For instance: What are the relevant interpersonal dynamics of service employee and customer/client encounters - especially as they relate to individuals of different cultural backgrounds? Are such perceived cultural differences really pertinent? What are the problems and likely organizational coping strategies that arise out of divergent work-values between different classes of service staff?

5. The present study considered only service-providing organizations. A valuable contribution could be made to the overall task of better understanding services marketing by conducting research into the attitudes and behaviour of service customers and clients. Very little objective insight exists, for example, with regard to service clients' risk perceptions, quality evaluation processes, and responses to such organizational factors as corporate image, staff behaviour, and the provision of tangible service cues or proxies. 


\section{Reforences}

Benn, A. 1978. The 27 Most Common Mistakes in Advertising. New York: Amacom.

Berry, L.L. 1980. Services Marketing is Different. Bus., May-June, 24-29.

Bloom, P.N. 1984. Effective Marketing for Professional Services. Harv. Bus. Rev., vol.62, September-October, 102-110.

Bowen, D.E. \& Jones, G.R. 1986. Transaction Cost Analysis of Service Organization-Customer Exchange. Acad. Manage. Rev., vol.11, 428-441.

Carman, J.M. \& Langeard, E. 1980. Growth Strategies for Service Firms. Strat. Manage. J., vol.1, January-March, 7-22.

Chase, R.B. \& Tansik, D.A. 1983. The Customer Contact Model for Organizational Design. Manage. Sci., vol.29, September, 1037-1050.

Doyle, P. \& Corstjens, M. 1983. Optimal Growth Strategies for Service Organizations. J. Bus., vol.56, 389-405.

Gronroos, C. 1984. A Service Quality Model and Its Marketing Implications. Europ. J. Market., vol.18, 36-44.

Hawes, D.K. \& Arndt, J. 1979. Determining Consumer Satisfaction Through Benefit Profiling. Europ. J. Market., vol.13, 284-298.

Knisely, G. 1984. Service Business is People Dealing with Other People. In: Services Marketing: Text, Cases and Readings, Lovelock, C.H., Ed., Englewood Cliffs: Prentice Hall, 24-29.

Kotler, P. \& Levy, S.J. 1971. Demarketing, Yes Demarketing. Harv. Bus. Rev., vol.49, November-December, 74-80.

Levitt, T. 1972. Production-Line Approach to Service. Harv. Bus. Rev., vol.50, September-October, 41-52.

Levitt, T. 1976. The Industrialization of Service. Harv. Bus. Rev., vol.54, September-October, 63-74.

Lovelock, C.H. \& Young, R.F. 1984. Look to Consumers to Increase Productivity. In: Services Marketing: Text, Cases and Readings, Lovelock, C.H., Ed., Englewood Cliffs: Prentice Hall, 260-271.

Marketing Mix, Promodata '86: Promotion, Marketing and Advertising Data. 1986. Johannesburg: Systems Publishers, 122-129.
McCarthy, E.J. 1964. Basic Marketing: A Managerial Approach. 2nd Edition. Homewood: Richard D. Irwin.

Mills, P.K., Chase, R.B. \& Margulies, N. 1983. Motivating the Client/Employee System As A Service Production Strategy. Acad. Manage. Rev., vol.8, 301-310.

Newton, D.A. 1965. Advertising Agency Services: Make or Buy? Harv. Bus. Rev., July-August. Reprinted in Harvard Business Review Reprint Series, Advertising: Better Planning, Better Results. no.2 1020, no date, 107-114.

Normann, R. 1984. Service Management: Strategy and Leadership in Service Businesses. Chichester: John Wiley \& Sons.

Porter, M.E. 1980. Competitive Strategy: Techniques for Analyzing Industries and Competitors. New York: The Free Press.

Riddle, D.I. 1986. Service-Led Growth: The Role of the Service Sector in World Development. New York: Praeger Publishers.

Rushton, A.M. \& Carson, D.J. 1985. The Marketing of Services: Managing the Intangibles. Europ. J. Market., vol.19, $19-40$.

Sasser, W.E. 1976. Match Demand and Supply in Service Industries. Harv. Bus. Rev., vol.54, November-December, 133-140.

Schneider, B. 1980. The Service Organization: Climate is Crucial. Organ. Dynamics, Autumn, 52-65.

Shostack, G.L. 1977. Breaking Free from Product Marketing. J. Market., vol.41, April, 73-80.

Surprenant, C.F., Czepiel, J.A. \& Solomon, M.R. 1985. The Service Encounter: Managing Employee/Customer Interaction in Service Businesses. Lexington: Lexington Books.

Surprenant, C.F. \& Solomon, M.R. 1987. Predictability and Personalization in the Service Encounter. J. Market., vol.51, April, 86-96.

Thomas, D.R.E. 1978. Strategy is Different in Service Businesses. Harv. Bus. Rev., vol.61, July-August, 158-165.

Zeithaml, V.A., Parasuraman, A. \& Berry, L.L. 1985. Problems and Strategies in Services Marketing. J. Market., vol.49, Spring, 33-46. 